\title{
Mineral Association, Gold Mineralization and Deposit Type of The Reza Gold Deposit (Gedabek Ore District, Lesser Caucasus, Azerbaijan)
}

\author{
Imamverdiyev Nazim ${ }^{1 *}$, Babazadeh Vasif ${ }^{1}$, Mursalov Samir², Veliyev Anar ${ }^{2}$ and Abdullayeva Shakhla ${ }^{1}$ \\ ${ }^{1}$ Department of Geology, Baku State University, Azerbaijan \\ ${ }^{2}$ Azerbaijan International Mining Company Limited, Azerbaijan
}

Submission: November 22, 2019; Published: December 10, 2019

*Corresponding author: Imamverdiyev Nazim, Department of Geochemistry, Baku State University, Azerbaijan

\begin{abstract}
In article described Reza gold deposit of Ugur exploration area located in Gedabek Ore District of the Lesser Caucasus in NW of Azerbaijan. It is established that high quality gold is observed in the following mineral association: oxide mineralization; transition zone mineralization; sulfide mineralization. The high-grade gold observed in the following mineral association: barite-hematite-quartz-kaoline; hematite-quartzkaoline; barite-sulfide-quartz. The low-grade gold observed in the following mineral association: disseminated pyrite; stock-stockwork pyrite; disseminated and veinlets covellite-pyrite (+/- turquoise) mineral associations. Deposit alteration signature has characteristics which suggest the current outcrop level may be near the top of a mineralized, gold-bearing high sulfidation epithermal (HSE) system. The gold mineralization at the deposit is interpreted as forming in shallow high sulfidation epithermal systems. The mineralization has been noted to occur in two different styles: well-confined hydrothermal breccias; associated with pyrite stock-stockwork. Most of the deposit material and current estimates are formed within the barite-hematite-quartz-kaoline mineralization in the secondary quartzite rocks. The main brecciation and stockwork are hosted within secondary quartzite, sometime massive silicified andesite porphyritic rocks.
\end{abstract}

Keywords: Reza gold deposit; Gedabek Ore District; Lesser Caucasus; Mineral association; Gold mineralization; High sulfidation epithermal systems

\section{Introduction}

Gedabek ore district is in the territory of Shamkir uplift of the Lok-Karabakh island arc volcanic structural-formation zone in the Lesser Caucasus Mega-anticlinorium. The ore region has a complex geological structure, and it has become complex with the intrusive masses and breaking structures of different ages and different composition. Lower Bajocian is essentially composed of an uneven succession of diabase and andesite covers, agglomerate tuffs, tuff-gravelites and siltstones. Tuff facies of the Lower Bajocian were exposed to strongly metamorphism (skarn alteration and hornfelsing) as a result of the impact of Upper Bajocian volcanism and intrusives of Upper Jurassic age. Only subvolcanic facie of the Upper Bajocian in the Gedabek mine has been studied (rhyolite and rhyodacite, quartzporphyry). Rocks related to the Bathonian stage have developed mainly in the northern and southern edges of Shamkir uplift [1]. Gedabek ore district and Shamkir uplift in general is complex in terms of its tectonic structure and its magmatism is complex too. Magmatic processes in this region have occurred intensely. There are 3 phases of magmatism in the ore area:
a) Bajocian phases
b) Bathonian phases
c) Upper Jurassic phases (Figure 1)

The Bajocian phase is divided into two autonomous substages:

Lower Bajocian age rocks - intermediate and basic composition pyroclastic volcanic and volcanic disturbed rocks occupy the central portion of Shamkir uplift, and have become complex with intrusive and subvolcanic complexes and breaking structures of different ages, morphology. Acid composition products of the Upper Bajocian magmatism are represented very broad by all facies within Gedabek ore district. It can be considered that the magmatic center of the Upper Bajocian period is in the Shamkir uplift. Andesite, partially andesite-basalt composition products of the Bathonian phase of magmatism, as well as various composition pyroclastic materials and lava flows Upper Jurassic phase are spread mainly in the sidelines of 
Shamkir uplift. Along the breaking's structures and in the areas between them, rocks along micro cracks have become strongly quartizated, kaolinized, sericitized and in most cases changed to secondary quartzite. Breaking structures have not caused Lower Bajocian rocks to become too complex. The main complexity was generated by subvolcanic masses of rhyolite, rhyodacite and quartz-porphyry composition of Upper Bajocian age which occurred along the Gedabek-Bittibulag depth fault and which began to cool down in the area close to the surface. Rhyolites and rhyodacites changed to various types of secondary quartzite, and the surrounding rocks changed into secondary quartzite, skarn rocks and hornstones depending upon petrographic, mineralogical and lithological compositions. However, the processes mentioned above did not occur all through the subvolcanic masses and contact rocks. These processes occurred in such areas where there was a constant contact (open channel or open contact zone) between the subvolcano and magmatic source. One of such areas was the Misdag area in which Gedabek mineral deposit (mine) is located [2-4].

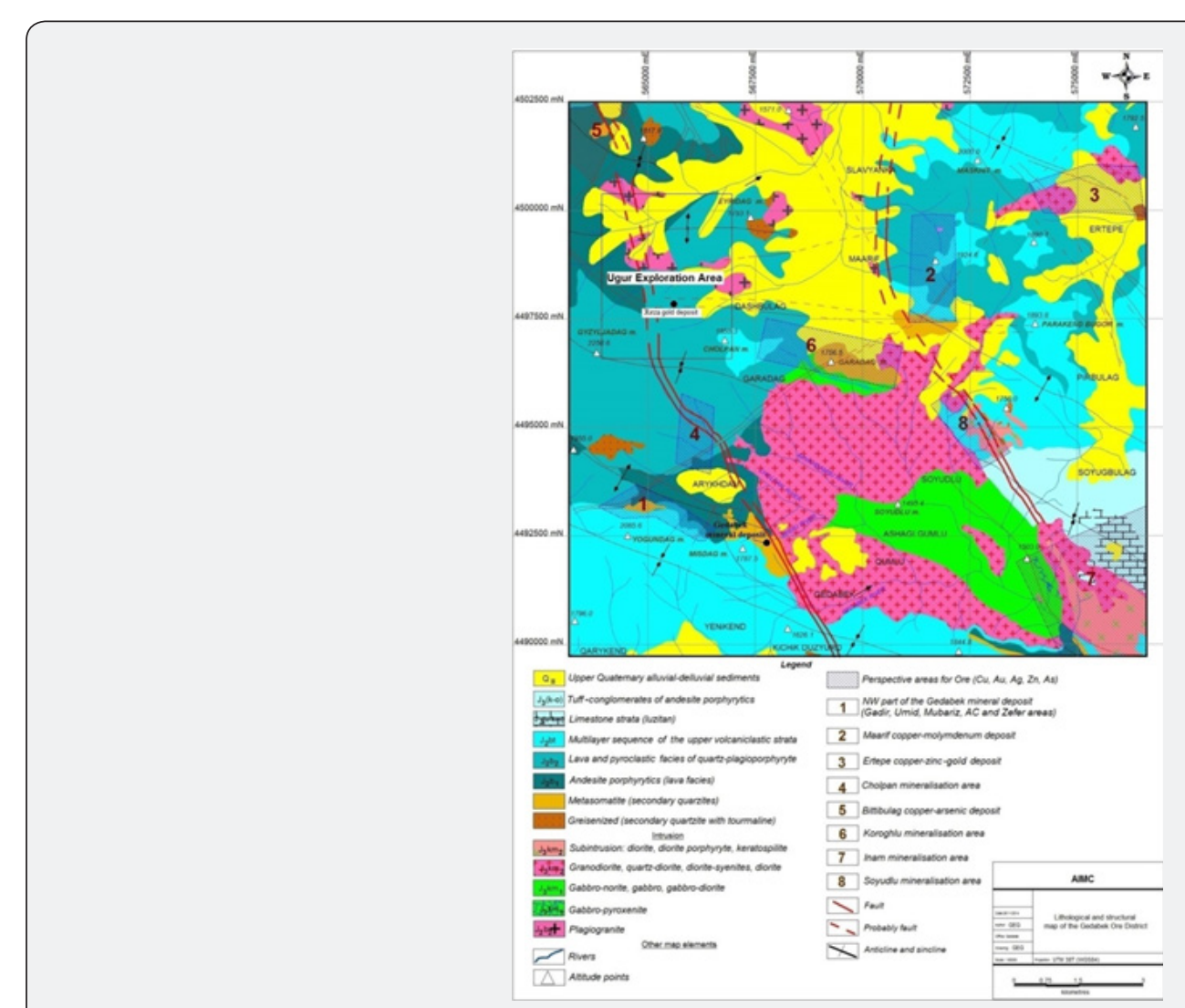

Figure 1: Lithological-structural map of the Gedabek Ore District (perspective areas for $\mathrm{Cu}, \mathrm{Au}, \mathrm{Ag}, \mathrm{Zn} \& \mathrm{As}$ ).

The Reza gold deposit is in Gedabek Ore District of the Lesser Caucasus in NW of Azerbaijan, 358 kms East of the capital city Baku, $48 \mathrm{kms}$ East of the city of Ganja and Ganja airport, $4.7 \mathrm{kms}$ NW of Gedabek open-pit gold copper mine. The deposit is well within the Ugur exploration area, NW Area polygon of Gedabek Contract Area. Deposit was discovered in 2016 year by GEG and called Reza for honour of Reza Vaziri, which is president of Azerbaijan International Mining Company, Anglo Asian Mining PLC [5]. The exploration centre of the project is the partially backfilled outcrop, independently located on Google Earth at Latitude $40^{\circ} 37^{\prime} 13.10^{\prime \prime} \mathrm{N}$ and Longitude $45^{\circ} 46^{\prime} 15.34^{\prime \prime} \mathrm{E}$. The known gold mineralization has an estimated north-south strike length of $400 \mathrm{~m}$ and a total area of approximately 20 hectares or $0.2 \mathrm{~km}^{2}$. The deposit is enlarged by highly gold-silver result of surface outcrop rock chip samples over an area of $2.5 \mathrm{kms}$ NorthSouth by $2 \mathrm{kms}$ East-West, with the Reza gold deposit located on the central part. In a geological structure of section there were participated secondary quartzites being formed under the influence of Atabek-Slavyanka plagiogranite intrusion exposures observed to the north from the gold mineralization area. The area in tectonic attitude is confined to Gyzyldjadag fault of Northeastern sub-latitudinal strike $80^{\circ}$ with a vertical dip. The mineralization zone thickness within the area bounds is up to 80-120m. Rocks in the alteration zone area crumpled, argillic alterated, brecciated, strongly limonitized and hematitized. Out of metallic minerals there observed crystalline hematite. On surface observed intensive barite and barite-hematite vein and veinlets, also gossan zones. The main mineralization zones have been sampled in three trenches at a distance up to $270 \mathrm{~m}$ by trenches \#1, \#2 and \#3 and received positive results for gold and silver. Also, there have taken approximately 550 samples from outcrop \#1 and \#2. 
(Figure 2) Lithological-structural map of the Reza gold deposit, Ugur exploration area, scale 1:2800, A3 format, Original

scale 1:1 000 (by GEG, 2016). Legend of lithological-structural map (Figure 2.1):

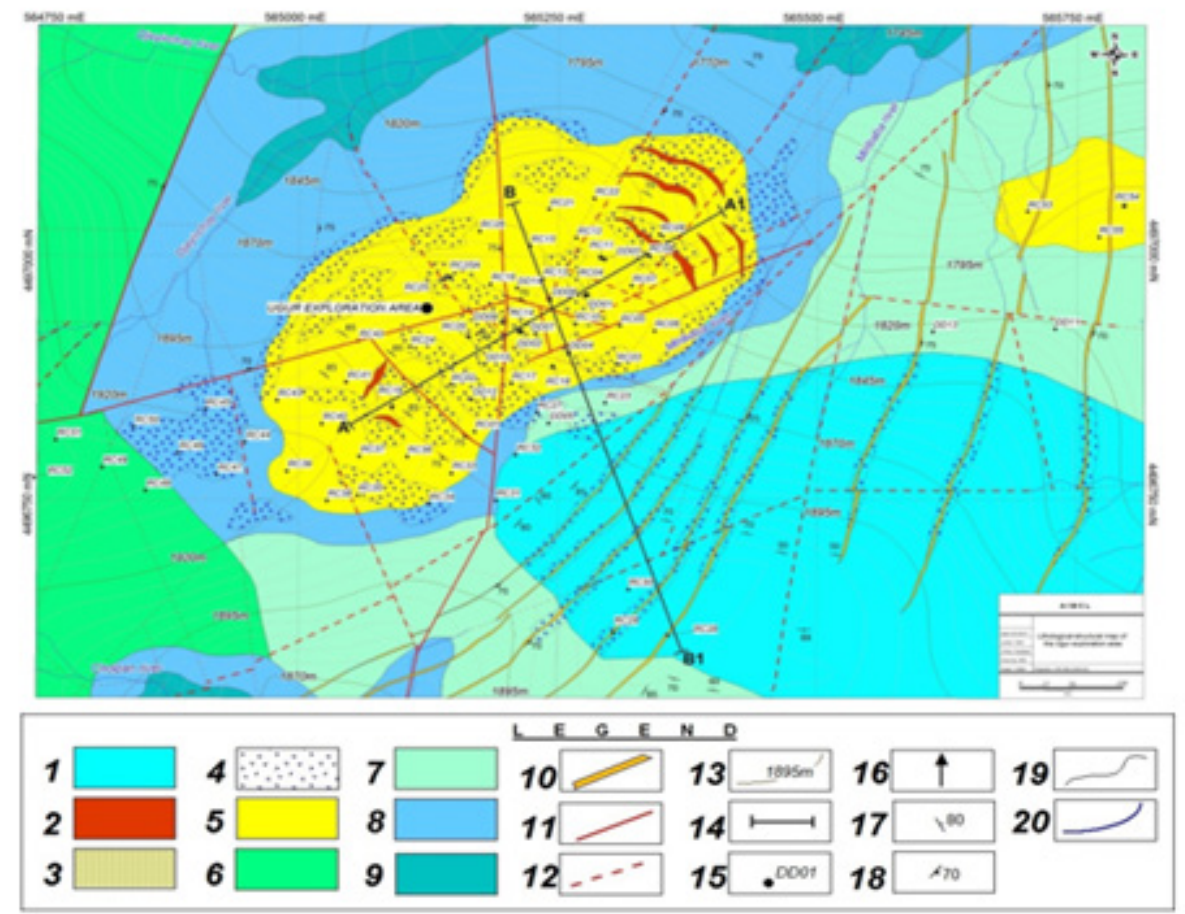

Figure 2: Lithological-structural Map of the Reza Gold Deposit, Ugur exploration area, scale 1:2800, A3 format, Original scale 1:1 000 (by GEG, 2016). Legend of lithological-structural map: 1) Andesite tuff agglomerates facie; 2) Gossan; 3) Pyrite stock and stockverk; 6) Breccia zone of silicified andesite porphyritic rocks; 5) Secondary quartzite; 6) Pyroclastic (from small clastic to lapilli) facie of rhyolite-dacite porphyry; 7) Lava facie of rhyolite-dacite porphyry; 8) Silicified andesite porphyritic rocks; 9) Andesite porphyritic rocks; 10) Quartz porphyry zone (weak hematitized, limonitezation); 11) Faults; 12) Probably faults; 13) Topographic contour line; 14) Cross section lines; 15) Bore holes points; 16) Bore holes ; 17) Deep angle of faults and dykes; 18) Structural elements of rocks; 19) Lithological contact; 20) Rivers.

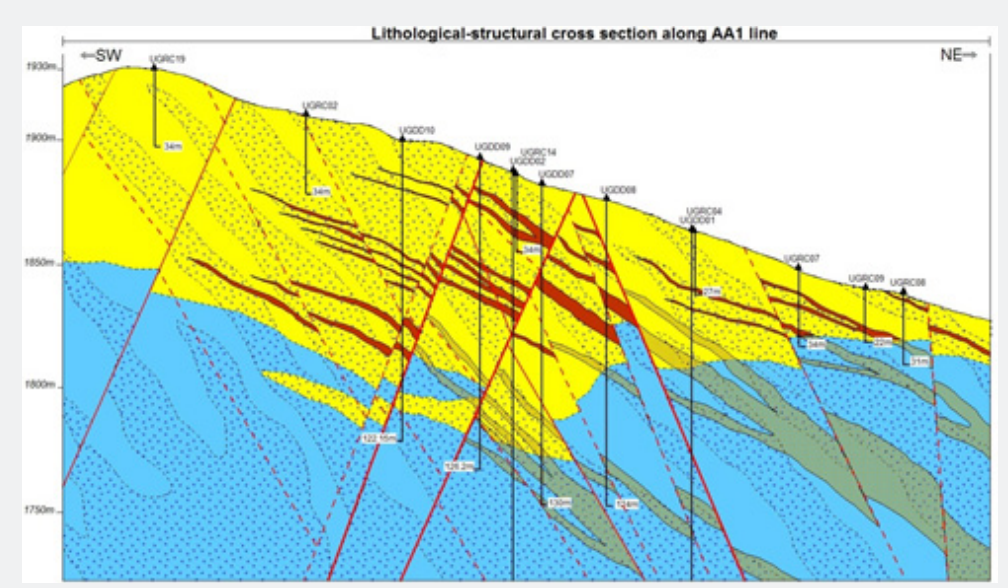

Figure 2.1: Lithological-structural Cross Section along AA1 line, Reza Gold Deposit of the Ugur exploration area.

a) Andesite tuff agglomerates facie

b) Gossan

c) Pyrite stock and stockverk

d) Breccia zone of silicified andesite porphyritic rocks e) Secondary quartzite

f) Pyroclastic (from small clastic to lapilli) facie of rhyolite-dacite porphyry

g) Lava facie of rhyolite-dacite porphyry 
h) Silicified andesite porphyritic rocks

i) Andesite porphyritic rocks

j) Quartz porphyry zone (weak hematitized, limonitezation)

k) Faults

1) Probably faults

m) Topographic contour line

n) Cross section lines

o) Bore holes points

p) Bore holes

q) Deep angle of faults and dykes

r) Structural elements of rocks

s) Lithological contact

t) Rivers

On the main orebody at surface centre have occured secondary quartzites with vein-veinlets barite-hematite mineralization over which remain accumulations of hydrous ferric oxides cementing breccias of quartz and quartzites. And in erosion parts observed "reddish mass" being oxidation product of stock and stockverk hematite ores. Representing typical gossans, these accumulations by the data of trenches for thickness about 5-10m contain gold 0.3-2.0 g/t and silver 1.0$15.0 \mathrm{~g} / \mathrm{t}$.

\section{Local Geological-Structural Setting}

The gold mineralization in the Reza deposit developed mainly during the Upper Bajocian tectonic-magmatic cycle. Tectonic zone is the main host structure for the West (central zone) and East zones of gold mineralization. During Upper Bajocian times, the central tectonic zone was a right-lateral strike-slip fault represented by several sub-parallel-trending faults (55o-85o) with a combined length of 1-1.5 kilometers. The fault dips from $70 \mathrm{o}$ to $80^{\circ}$ to the north-west. The faults of the central zone control the hydrothermal metasomatic alteration, gold mineralization, Upper Bajocian Atabek-Slavyanka plagiogranite massive intrusion, and in some cases are the borders of the elevated tectonic blocks formed by Lower Bajocian volcanic rocks. The East tectonic zone is complicated by the occurrence of numerous related faults such as antithetic and synthetic faults, down throw and thrust faults and intense folding due to faulting. The combination of these structures determines the general morphology of both the oxide and primary sulfide mineralization. Where zones of either fracture cleavage or quartz veinlets occur in drill core, these intervals are described as fault zones. In many cases the intervals of faulting are represented by tectonic breccias in which relics of the host volcanic-sedimentary rocks are cemented by dacitic rock. The tectonic breccias probably formed after emplacement of the sulfide mineralization, during the formation of the sub-longitudinal faults. The intervals of tectonic breccia exhibit lower gold grades in comparison with zones of fracture cleavage and quartz veinlets [6].

The Reza gold deposit was emplaced in the intersection of NW, NE, N and E trending structural systems regionally controlled by a first order NW transcurrent structure. Structure geometry and kinematics determined from surface mapping and drilling information suggest that the volcanic sequence hosted at central part might have been accumulated in a "pull-apart" basin controlled by NW structures. These structures were affected by two compressive deformation processes: the first as a result of the $\mathrm{N}$ to the NNE sub-horizontal contraction and the second being formed during a post mineral NW contraction. Field geological exploration information, cross-cutting relationships between structures, veins and brecciation types and hydrothermal alterations styles suggest that the mineralization was controlled by NW brittle dextral shears, associated with E-W left lateral and $\mathrm{N}-\mathrm{S}$ pure extensional structures, with all them related to the contraction event within a transpressional regimen.

\section{Mineralization and Hyrdothermal Alteration}

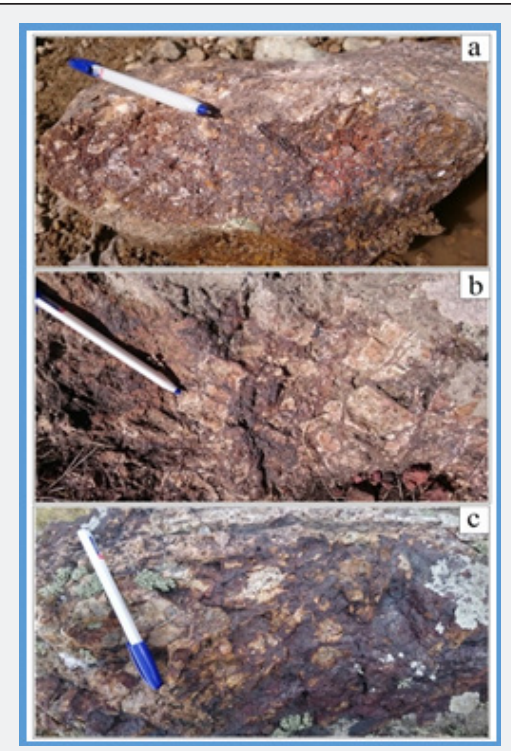

Figure 3: Breccia, Oxide Mineralization style of Reza Gold Deposit: a) Barite-hematite mineralization main orebody (rock sample taken from Djayirchay river by GEG, 2016), Au assay result is $4.96 \mathrm{ppm}$; b) Secondary quartzite breccies is rectangle form (outcrop, near trench 02 ), Au assay result is $0.7 p p m ; c$ ) Secondary quartzite breccies is round form (outcrop, near trench $01)$, Au assay result is $0.6 \mathrm{ppm}$.

Main mineralization in the Reza gold deposit consists of hematite-barite-quartz-kaoline veins-veinlets and breccia, pyrite stock-stockverk and quartz-sulfide veins (Figure 3). On the main orebody surface centre have occurred secondary quartzites with vein-veinlets barite-hematite mineralization over which remain accumulations of hydrous ferric oxides cementing breccias of quartz and secondary quartzites. And in erosion parts observed 
"reddish mass" being oxidation product of stock and stockverk limonite-hematite ores. Representing typical gossans, these accumulations by the data of trenches for thickness about $5-10 \mathrm{~m}$ contain gold 0.3-3.5 ppm and silver 1.0-45.0 ppm [7,8].

This is three zones of gold mineralization within the Reza gold deposit:

a) Oxide mineralization

b) Transition zone mineralization

c) Sulfide mineralization

The oxide gold mineralization consists of clay-gravel weathering crust of kaolinite type. The most common colour of the oxide is greenish-yellow with different shades of white, brown and red. Strongly oxidized rhyodacite and dacite are represented by light green and grey colour rock, oxidized andesite porphyritic rock has a brown and red colour. The gold-bearing mineralization has been oxidized to a depth of approximately 50-100 metres. Locally, in areas of shallow, vertical fracturing and faulting, oxidation has progressed to greater depth than the average profile. Typically, the gold mineralization is coarser and a minor increase in gold grade occurs within the oxides compared to the original rocks. The nugget effect increase in the gold grade of the oxides does not exceed approximately 10\%. Underlying the oxidized unit, a semi-oxidized horizon displays a partial level of oxidation with some remaining sulfides (transition zone) and may be treatable for its gold content but with lower recoveries.

\section{Mineral Associations}

The high-grade gold observed in the following mineral association (based on assay data):
1. Barite-hematite-quartz-kaoline

2. Hematite-quartz-kaoline

3. Barite-sulfide-quartz

The low-grade gold observed in the following mineral association:

4. Disseminated pyrite

5. Stock-stockwork pyrite

6. Disseminated and veinlets covellite-pyrite (+/turquoise) mineral associations.

The 2-3 stages associations are clearly connected with the mineralization process. Each association can occur separately, spots and impregnations. As well, these alteration packages can occur rocks. Disseminated pyrite observed all primary rock in the deposit.

Barite-hematite-quartz-kaoline: The dominant style of mineralization on the project is from $1 \mathrm{~cm}$ to $1 \mathrm{~m}$-wide veins filled with variable amounts of red hematite, specular hematite, and quartz. In outcrop the dominant mineral is earthy red hematite, which is ubiquitous in these stockwork, but remnant patches and stockwork of barite can be found, indicating that the red hematite is likely a weathering product of hypogene barite. Larger stockwork include higher amounts of quartz. Many veinlets contain vugs and open-space-filling textures of euhedral quartz and kaoline. The majority of hematite-barite- quartzkaoline mineralization observed to date occurs as sub-decimeter fractures, either as individual veinlets, zones of parallel sheeted veinlets, or networks of cross-cutting veinlets in some places forming stockwork zones (Figure 4).

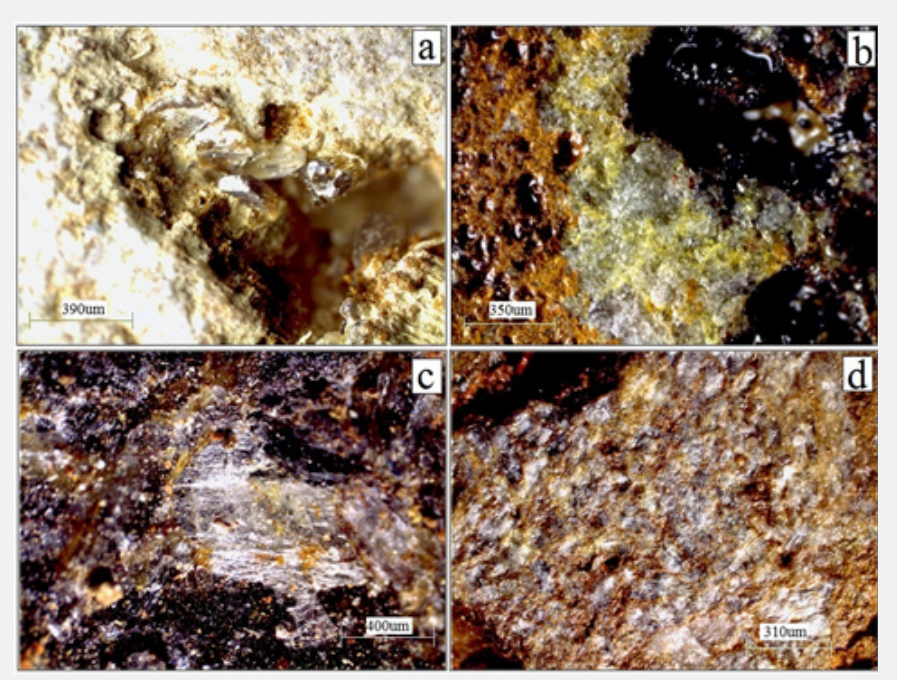

Figure 4: Barite, Barite-hematite, Barite-hematite-limonite Mineralization main type of Orebody from Core piece (photos taken under Leica S8AP0 Binoculars): a) Barite grains in vugs, secondary quartzite (12.2m, UGDD01); b) Barite-hematite-limonite veinlets in secondary quartzite (14m, UGDD01); c) Barite-hematite-limonite mineralization association, breccia form in secondary quartzite (39.4m, UGDD02); d) Barite-hematite-limonite mineralization association, like "fish scale" form in secondary quartzite (40.5m, UGDD02). 
The hematite-quartz-kaoline: association is the earliest stage and can occur in both mineralized zones and in silicified host rocks. Macroscopically this association exhibits brown red colouration of accompanying quartz. The thickness of the stockwork veinlets ranges from 1 millimetre to 3-5 centimetres. The borders of this style of alteration are usually uneven, often exhibiting pinchand-swell forms and relics of the original rocks.

Barite-sulfide-quartz: is the main mineral association of economic interest. This association forms thin (a few millimetres to 1-2 centimetres) veins and small impregnations within sericitized and silicified rocks. The spatial occurrence of the hematite-pyrite-quartz and barite-sulfide-quartz association forming single veins is common. In this case, the earlier hematitepyrite-quartz association occurs in the center of rock fragments while the barite-sulfide-quartz association occurs as a selvage. Sometimes hematite-pyrite-quartz and barite-sulfide-quartz crosscut each other and/or occur separately.

Disseminated pyrite: The first stage of mineralization is mainly represented by disseminated pyrite occurring together with quartz and adularia alteration through the below contact of the deposit. Gangue minerals are mainly represented quartz and adularia, and minor chalcopyrite. The size of disseminated pyrite is inferior to $1 \mathrm{~mm}$, but the intensity of pyrite dissemination is variable in different parts of the andesite porphyry (Figure 5).

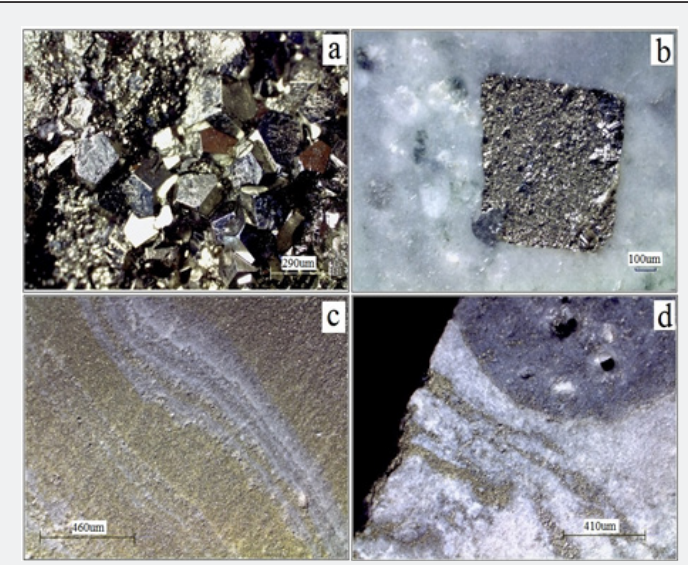

Figure 5: Pyrite mineralization type of sulfide orebody, Reza Gold Deposit: a) Dodecahedron pyrite crystal (70.7m, UGDD03); b) (319.2m, UGDD02); c) Banded pyrite-quartz vein (116.2m, UGDD02); d) Pyrite veinlets in secondary quartzite (89.2m, UGDD02).

Stock and stockverk pyrite: mineralization observed in the sulfide zone of the deposit.

The Pyrite-covelite-quartz: association is less common than the barite-quartz-sulfide association and usually forms veinlets, spots and disseminated aggregates in host (below contact rocksrhyolite and rhyodacite) rocks disseminated pyrite occurs. Pyrite and covellite are the main minerals of the association.
Pyrite occurs as grains (3-5 millimetre) in quartz and rarely as vein-like aggregates and selvages on quartz spots up to $0.5-1$ centimetres in thickness. Covellite usually occurs as needle-like crystals, from 2 to 8 millimetres long, and occurs around pyrite and sometimes replaces pyrite on its boundaries (up to complete replacement forming covellite pseudomorphs). Wolfromite (?) also occurs irregularly in veinlets and disseminated of pyritecovellite mineral association (Figure 6).

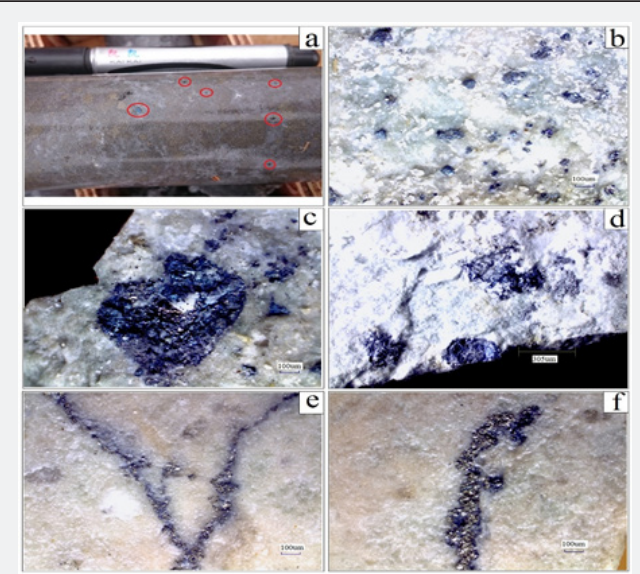

Figure 6: Sulfide mineralization style of Reza Gold Deposit: a) covellite minerals grains into secondary quartzite (from core piece); b) covellite grains (little size); c) covellite-pyrite -/+ wolfromite (high grade by XRF-?) minerals grains (coarse size); d) covellite -/+ wolfromite (high grade by XRF-?); e) \& f) covellite-pyrite veinlets in rhyodacite (?). 
constituents of the mineralized zones include:

\section{Ore Minerals}

The ore minerals are concentrated essentially as brecciastockwork and disseminated type mineralization in central part of the deposit. The stockwork zone has been developed due to ore-associated silica precipitation following the second boiling of the hydrothermal system, which was triggered by the AtabekSlavyanka plagiogranite intrusions. Ore minerals are mainly disseminated as fine grains in the stockwork of the brecciated secondary quartzite. Based on this research, metallic and gangue a) Metallic minerals

Pyrite, Chalcopyrite, Covellite, Chalcantite, Wolframite, Argentite? Acanthite?, Enargite?, Tenantite?, Arsenopyrite (rare), Cubanite?, Sphalerite (rare), Marcasite?, Tetrahedrite?

(?-mean that these minerals defined base on XRF data)

b) Gangue minerals

Barite, Calcite, Quartz, K-Feldspar, Muscovite-Sericite, Plagioclase, Clay (mainly, Kaolinite). Epidote, Chlorite, Hematite,

Tourmaline, Turquoise (Figure 7).

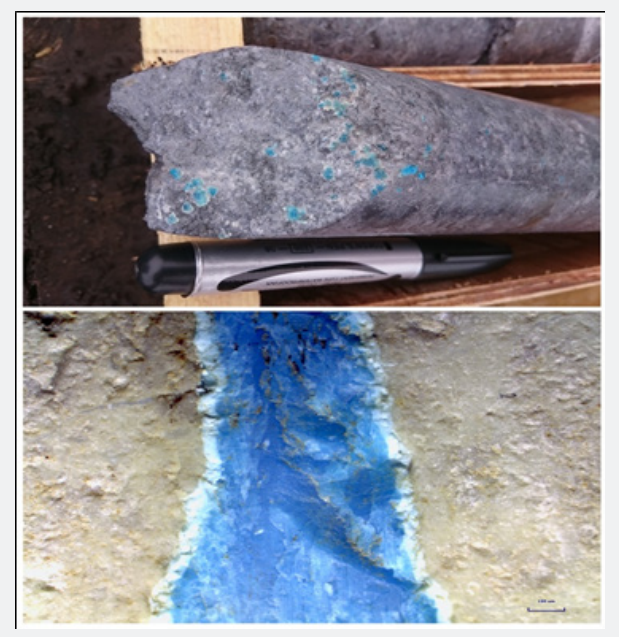

Figure 7: Turquoise $\left(\mathrm{CuAl}_{6}\left(\mathrm{PO}_{4}\right) 4(\mathrm{OH}) 8 \cdot 4 \mathrm{H}_{2} \mathrm{O}\right)$ Mineralization in the Reza Gold Deposit: Turquoise Minerals observed on Fractures, Rhyodacite core piece (the upper); Turquoise Mineral Fragment in Rhyodacite rock, photos taken under Leica S8AP0 Binoculars (the following).

Quartz: is the main mineral of this association. The grain

Pyrites: are observed as broken euhedral to anhedral crystals. The intergrowth of pyrite crystals and host rock inclusions in pyrites are common ore textures. Pyrite is represented by large 0.1 millimetre to 0.3 millimetre and rare 1.0 millimetre diameter) separate crystals or crystalline aggregates. Pyrite has a poor crystal shape. Spatially, pyrite occurs on the vein selvages and in the central part of sulphide mineral spots. Sphalerite forms relatively large ( 1 to 2 millimetre) grains in quartz veins. Usually, sphalerite grows around pyrite, "curing" small cracks inside pyrite grains. Pyrite and sphalerite occur as separate grains in the impregnated type of mineralization. Disseminated chalcopyrite grains occur in the center of sphalerite grains.

Hematite crystals: which are weathering products of early stage anhedral pyrite, are replaced by siderite due to carbonaterich weathering processes. Hematite is the most common ore mineral after pyrite, and it has been observed in different mineralogical features. The hematite contains randomly oriented crystals of barire and quartz in different sizes and shape. Textural relations suggest that the quartz is a replacement product of chalcopyrite. size ranges from 0.01 to 0.1 millimetres with the $0.01-0.03$ millimetre grain size being the most prevalent. Coarse-grained quartz (usually 0.07 to 0.09 millimetres in diameter) occupies the central parts of small veins and spots. Quartz grains exhibit round shapes and/or oblong forms. Hematite is unevenly distributed and usually colours fine-grained quartz in some instance. Pyrite exhibits pyritohedron shapes and rarely cubic crystal habits. The pyrite grains range in size from 0.05 to 0.2 millimetre and occur inside clear quartz grains.

In addition to the minerals described above, thin-flakes of sericite can occur in the centre of the quartz veins and spots and can be replaced by chlorite or chlorite-ankerite. Chlorite occurs only in contact with carbonate with sericite forming the edges between these minerals. Chalcopyrite rarely occurs together with pyrite and forms thin veinlets and impregnations.

\section{Hydrothermal Alteration}

At the deposit, mineralization occurs with strong argillic alteration, with stockwork, disseminated, and veinlets, within secondary quartzite breccias and mineralized east-northeast structures. Oxide facies dominate at the surface but become 
sulfide mineralization at depths of less than 50-100m. Two distinct alteration events are recognized by GEG AIMC, 2016. During emplacement, the early granodiorite intrusions altered the andesite porphyritic rocks. Later, the main mineralization altered the silicified andesite porphyritic and secondary quartzite rocks generating a zoned alteration assemblage that includes moderate to selective quartz, sericite, argillic and silicification alteration among others. Alteration to kaolinite and iron oxides occur locally, as does an apparent epithermal overprint that produces banded and chalcedonic textures, and which may be associated with observed barite-hematite and pyrite mineralization. Gold at Reza deposit is concentrated in the gossan, argillic and limonitezation-hematitized alteration zones and low-grade gold in phyllic zone (pyrite stock and stockwork). Transition zone at the oxide-phyllic zones boundary is largely north-south trending fault-controlled silica flooding, which becomes northeast striking, east and west of the boundary. The deposit alteration studies about 20-25pcs samples from intrusive and host rock showed in order of dominance, intermediate argillic, propylitic, advanced argillic, phyllic, silicification and gossan alteration zones. The dominant types of alteration on the project are hematite alteration and secondary mineralization of pyrite (Figure 8). Minor silicification and clay alteration of andesite porphyritic rocks are also present. Hematite alteration consists of hematite staining surrounding hematite-baritequartz association. This type alteration is accompanied in some places by silicification and limonitezation.
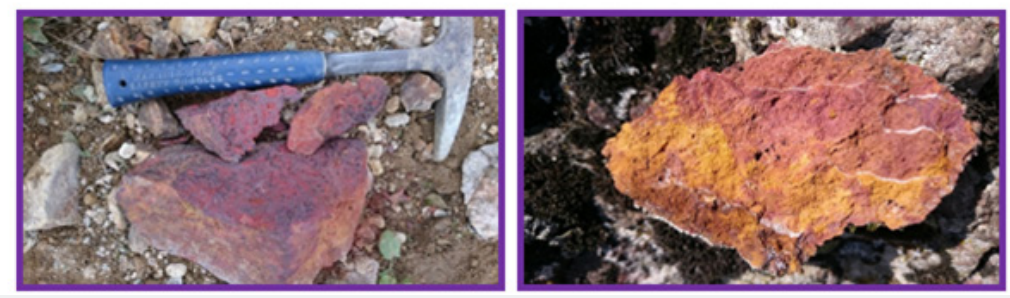

Figure 8: Hematite Mineralization, oxide zone: Left side-hematite vein on Andesite Porphyritic Fractures and Right side- Barite Veinlets Oxidation Secondary Quartzite.

\section{Deposit Type}

The remote sensing anomalous (in NW and SW) area is believed to remain open in all directions under shallow, postmineral cover. Deposit alteration signature has characteristics which suggest the current outcrop level may be near the top of a mineralized, gold-bearing high sulfidation epithermal (HSE) system [9-11]. The gold mineralization at the deposit is interpreted as forming in shallow high sulfidation epithermal systems. The mineralization has been noted to occur in two different styles:

a) well-confined hydrothermal breccias

b) associated with pyrite stock-stockwork

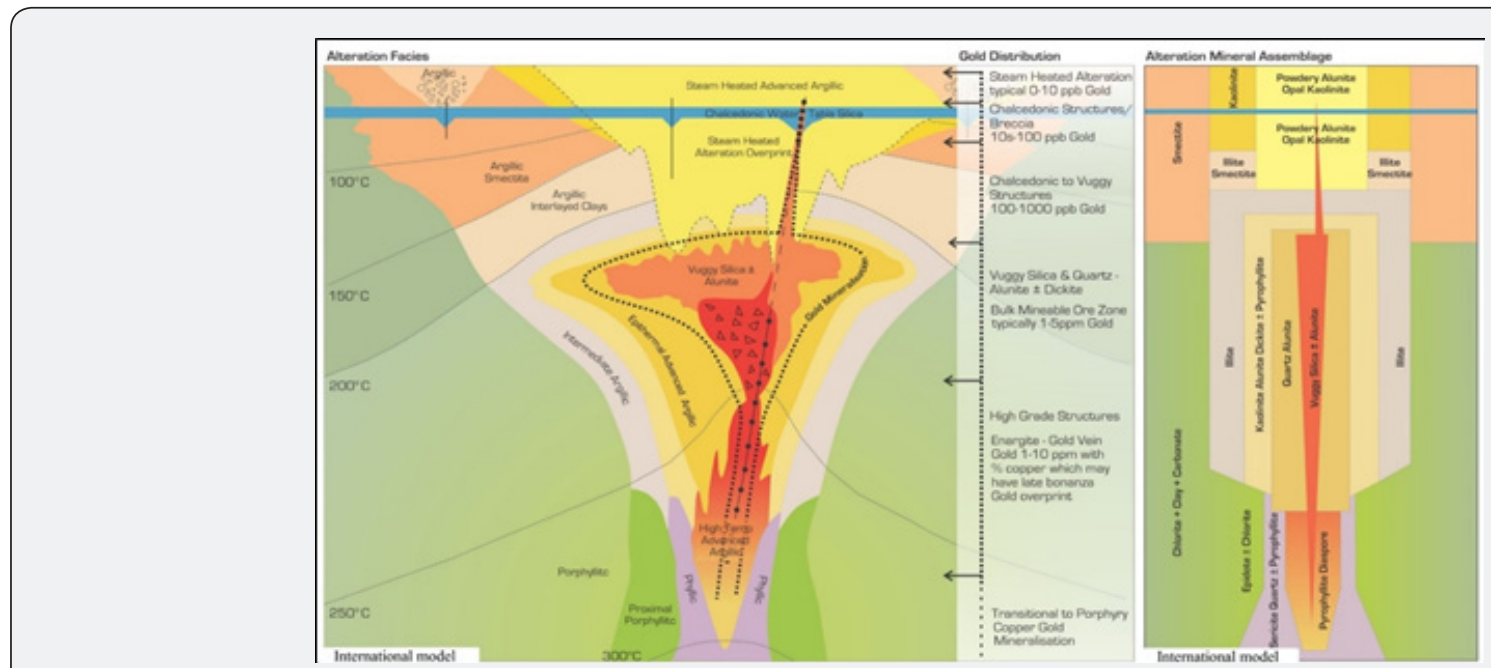

Figure 9: International High Sulfidation Epithermal Model for the Reza Gold Deposit.

Most of the deposit material and current estimates are formed within the barite-hematite-quartz-kaoline mineralization

in the secondary quartzite rocks. The main brecciation and stockwork are hosted within secondary quartzite, sometime massive silicified andesite porphyritic rocks [12]. Outcropping 
gold mineralization at the project is oxidized with no sulfides recognized at surface. Mineralization is hosted by brecciated, and intense advanced argillically-altered andesitic volcanics and possible domes, including large areas of "powdery" probably alunite-opal alteration (Figure 9). The outcropping alteration at the deposit is typical of the upper steam-heated levels of highsulfidation epithermal (HSE) deposits, which in most mineralized systems of this type, may cap higher-grade gold mineralization which is hosted by underlying vuggy and oxide zones. From our current mapping and sampling, the gold mineralization at the deposit appears to form a crescent shape surrounding a "core" of barite-hematite mineralization in advanced argillically \& silicification - altered porphyritic andesite host rock.

\section{References}

1. Abdullaev RN, Mustafaev GV, Mustafaev MA, et al. (1988) Mesozoic igneous formations of the Lesser Caucasus and related endogenous mineralization. Baku: Elm, pp. 158.

2. Baba-zadeh VM, Abdullaeva ShF (2012) Noble metal ore-magical systems. Baku: Baku University pp. 276.

3. Baba-zadeh VM, Veliyev AA, Abdullayeva ShF (2015) New perspective Gadir mineralization field in Gedabey ore region. Reports of Nationa Academy of Sciences of Azerbaijan 2: 74-79.

4. Baba-zadeh VM, Mursalov SS, Veliyev AA, Imamverdiyev NA Abdullayeva S, et al. (2019) Geochemical anomalies in the NW flank of Gedabek mine (Lesser Caucasus, Azerbijan). International Journal of Mining Science (IJMS) 5(1): 31-42.
5. (2014) AIMC Gedabek Exploration Group (GEG). Report about the results and future planning of the perspective areas $\mathrm{Au}, \mathrm{Ag}, \mathrm{Cu}, \mathrm{Mo}$, Zn) of Gedabek Ore District, Gedabek.

6. Novruzov N, Valiyev A, Bayramov A, Mammadov S, Ibrahimov J, et al. (2019) Mineral composition and paragenesis of altered and mineralized zones in the Gadir low sulfidation epitermal deposit (Lesser Caucasus, Azerbaijan). Iranian Journal of Earth Sciences 2(1): $14-29$

7. Valiyev A, Bayramov A, Mammadov S, Mursalov S, Ibrahimov RG, et al. (2016) Structural Geology, Lithology, Mineralization, and New Perspectives on the Gadir Low-Sulfidation Deposit, Gedabek District; a Newly Discovered Orebody in the Tethyan Metallogenic Belt, Lesser Caucasus, Azerbaijan. Society of Economic Geologists, Inc. SEG Conference, Chesme, Izmir, Turkey

8. Valiyev A, Bayramov A, Ibrahimov J, Mammadov S, Alizhadeh G, et al (2018) Geological Setting and Ore Perspective of the New Discovered Gadir Low Sulfidation Epithermal Deposit, Gedabek NW Flank, Lesser Caucasus, Azerbaijan. Universal Journal of Geoscience 6(3): 78-101.

9. Sillitoe RH, Hedenquist JW (2003) Linkages between volcanotectonic settings, ore-fluid compositions, and epithermal precious metal deposits. Special Publication-Society of Economic Geologists 10: 315343.

10. Sillitoe RH (2010) Porphyry copper systems. Economic Geology 105(1): 3-41.

11. Simmons SF, White NC, John DA (2005) Geological characteristics of epithermal precious and base metal deposits. Economic Geology $100^{\text {th }}$ Anniversary pp. 485-522.

12. Adamia Sh, Zakariadze G, Chkhotua T (2011) Geology of the Caucasus: a review. Turkish Journal of Earth Sciences 20: 489-544.

\begin{tabular}{l} 
Your next submission with Juniper Publishers \\
will reach you the below assets \\
- Quality Editorial service \\
- Swift Peer Review \\
- Reprints availability \\
- E-prints Service \\
- Manuscript Podcast for convenient understanding \\
- Global attainment for your research \\
- Manuscript accessibility in different formats \\
( Pdf, E-pub, Full Text, Audio) \\
- Unceasing customer service \\
Track the below URL for one-step submission \\
https://juniperpublishers.com/online-submission.php \\
\hline
\end{tabular}

